\title{
Evaluation of space adequateness of shrimp farms in Southern Brazil
}

\author{
RODRIGO R. FREITAS ${ }^{1}$, CARLOS HARTMANN ${ }^{2}$, PAULO R.A. TAGLIANI ${ }^{3}$ and LUÍS H. POERSCH ${ }^{1}$ \\ ${ }^{1}$ Universidade Federal do Rio Grande, Instituto de Oceanografia, Estação Marinha de Aquacultura, \\ Caixa Postal 474, 96201-900 Rio Grande, RS, Brasil \\ ${ }^{2}$ Universidade Federal do Rio Grande, Instituto de Oceanografia, Laboratório de Oceanografia Geológica, \\ Caixa Postal 474, 96201-900 Rio Grande, RS, Brasil \\ ${ }^{3}$ Universidade Federal do Rio Grande, Instituto de Oceanografia, Laboratório de Gerenciamento Costeiro, \\ Caixa Postal 474, 96201-900 Rio Grande, RS, Brasil \\ Manuscript received on April 28, 2009; accepted for publication on August 16, 2010
}

\begin{abstract}
In Rio Grande do Sul State, there are four marine shrimp (Litopenaeus vannamei) farms in the municipal districts of São José do Norte and Rio Grande, and other four with previous license for operation. Thus, the present study aimed to identify and characterize areas for marine shrimp farming located in the Southern portion of the Patos Lagoon estuary $\left(32^{\circ} 00^{\prime} \mathrm{S} 52^{\circ} 00^{\prime} \mathrm{W}\right.$ ) by employing the analysis of satellite remote sensing (Landsat TM and ETM $+/$ Google Earth), airborne remote sensing (35mm system ADAR 1000), terrestrial remote sensing (RICOH 500SE), and field expeditions, integrating data in a Geographical Information System (IDRISI Andes). As a result, the enterprises were built on coastal fields or in obliterated dune areas, which are favorable for cultivation. The proximity of possible consuming markets and local labor, relatively good access roads and local technical support also favor the projects. However, there must be caution in terms of changes in the original projects, which could cause environmental impacts and noncompliance of environmental norms, such as the occupation of salt marsh areas. Based on the obtained information, instruments can be created to help inherent legal decision-making to manage the activity for futures enterprises.
\end{abstract}

Key words: costal management, GIS, Patos Lagoon, shrimp farms.

\section{INTRODUCTION}

In Rio Grande do Sul State, Southern Brazil, marine shrimp (Litopenaeus vannamei) culture activity has been developed since the beginning of 2000. Currently, three productive farms are located in the city of São José do Norte and one in Rio Grande; five other farms still wait for authorization from the environmental agency to be installed in the cities of Torres, São José do Norte and Rio Grande.

With the development of new activities, an increase in environmental and socioeconomic impact risks may arise, making these cultures unsustainable. This is con-

Correspondence to: Rodrigo Randow de Freitas

E-mail: rodrigorandow@ig.com.br firmed by some examples of difficulties reported in countries that have witnessed an exponential growth of these activities, with consequent loss of productive, legal, and environmental control (FAO 1998, Poli et al. 2000, Pérez et al. 2002, Chen et al. 2005, Giap et al. 2005, Karthika et al. 2005, Primavera 2006).

For this reason, the development of such activities initially requires space planning, in order to adjust their location to the environmental and socioeconomic characteristics of the region. In this context, the information obtained from remote sensing at different levels and data generated by the application of geoprocessing tolls, along with land use and biological, geographical, hydrochemical and socioeconomic data, are useful for 
reaching this goal, assuring productivity increase and preservation of areas that are sensible to environmental changes (Kapetsky et al. 1988, Nath et al. 2000, Pérez et al. 2002, Freitas and Tagliani 2007, Giap 2005).

Therefore, the present study aims the identification and characterization of marine shrimp farm areas, supported by satellite and airborne Remote Sensing techniques and methods, as well as field expeditions. By gathering all information into a Geographic Information System, tools to assist inherent legal decisionmaking regarding the management of the activity could be created.

\section{MATERIALS AND METHODS}

The study area consisted of marine shrimp culture farms located in the cities of Rio Grande and São José do Norte, Southern portion of the Patos Lagoon estuary $\left(32^{\circ} 00^{\prime} \mathrm{S}\right.$ and $\left.52^{\circ} 00^{\prime} \mathrm{W}\right)$. This estuary comprises an area of approximately $10.144 \mathrm{~km}^{2}$ that extends to northeastsouthwest direction, parallel to the Atlantic Ocean, and is characterized by having a great economic and ecological importance (Fig. 1).

This study started with the identification and location of legal and operational farms using available images (ADAR 1000, Landsat TM and ETM+ and Google Earth). Afterwards, the images were overlapped in layers in order to characterize the stage, type of occupation and land use of the current and future aquaculture enterprises. With the analysis and interpretation of the images, it was possible to map and survey the areas occupied by shrimp culture activity in the Patos Lagoon estuary.

Utilizing the ADAR system (Airborne Data Acquisition and Registration System 1000) and digital aerial images (35mm) obtained between 2000 and 2003, it was possible to capture color air photographs in visible and infrared bands (Fontoura and Hartmann 2001). Flight altitude was $1100 \mathrm{~m}$, with a resolution of $0.5 \mathrm{mpp}$ (meters per pixel), and each photo covered an area of $1500 \times 1000 \mathrm{~m}$. The image bands were adjusted to R1/ G2/B3 with ERDAS Software, in order to present normal color composition. With the same software, the spectral response of the targets was obtained in a continuous way, resulting in a transversal profile of the study area.
Due to the lack of images representing the region where farms 1, 2 and 3 were located, the images available in Google Earth were used. Besides locating the areas where the enterprises were or will be constructed, the study also analyzed the space adequacy of the existing or future enterprises, in regard to the current law.

In situ images of the enterprises were captured using a camera with an integrated GPS (Ricoh 500SE). The method provided an accurate positioning, using coordinate WGS84 or MGRS. As soon as the image was registered, the data were embedded into the image archive heading. In all areas with operating farms or designed to future enterprises, such photos were obtained and georeferenced for further detailing of the area.

Thematic maps (at scale 1:100.000 equivalent to a resolution of $30 \mathrm{~m}$ ), each representing individual layers, such as soil types, vegetation, water bodies, public roads, slope, topography and land use capacity, were submitted to specific geoprocessing routines in the Idrisi Andes GIS system (ver.15.01) and integrated to a characterization/identification model specifically constructed for this study, as described below.

Thematic maps were analyzed using the proximity analysis (i.e., buffer zone) in order to define, for example, the optimal distances to environmental protection areas, public roads and water bodies. In the present study, different distances were adopted, based on the current legislation, for each considered variable (e.g., $15 \mathrm{~m}$ for public roads, $30 \mathrm{~m}$ for legal protected areas and 50 and $100 \mathrm{~m}$ for water bodies, depending on their extension)

\section{RESULTS AND DISCUSSION}

The use of aerial photographs has permitted monitoring and mapping of areas that require attention concerning the natural resource management (Meyer et al. 1997). Aerial survey techniques provide a level of details that allow the visualization of the landscape according to its structure and spatial-temporal distribution (Civco et al. 1986, Ustin et al. 1986). The use of this tool is justified by its low cost and generation of digital data, which can be easily incorporated into a GIS database.

Thus, besides the use of ADAR 1000 system images to define culture areas, the spectral response of the targets was obtained to sketch up a cross profile of the 


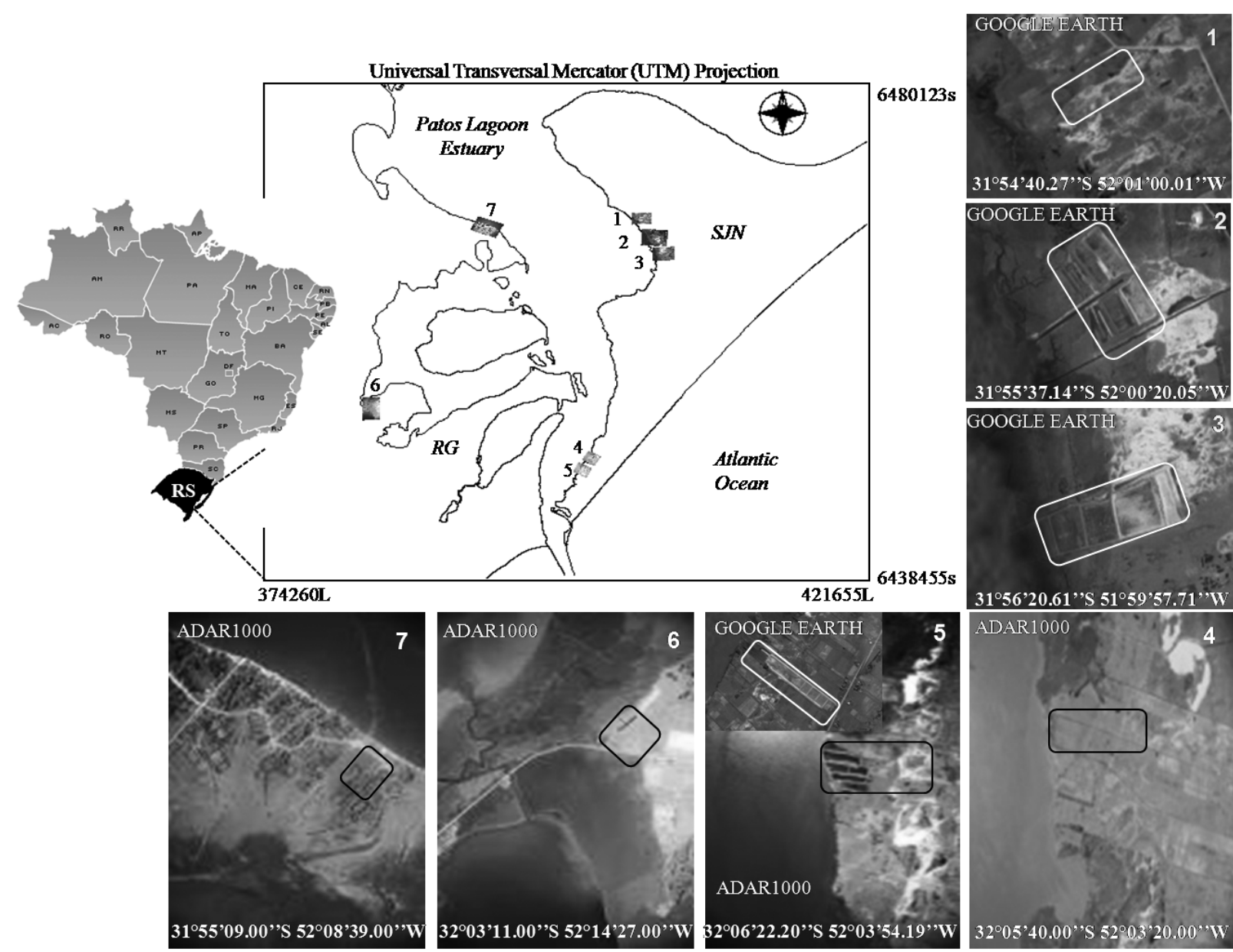

Fig. 1 - Study area map. (1-7: shrimp farm areas; RG: Rio Grande City; SJN: São José do Norte city; RS: Rio Grande do Sul State).

area using ERDAS software. ADAR 1000 system images were recorded with a $0.1 \mu \mathrm{m}$ or $100 \mu \mathrm{m}$ spectral resolution. The images for the areas of farms 6 and 7 were obtained in infrared mode (IR), and those for farms 4 and 5 in visible mode (VM).

The IR mode is an ideal method for vegetation and wetlands mapping. Similarly, lake waters and swamp areas (salt marshes) are highlighted due to the high absorption by water in the IR spectral range. For example, natural green vegetation (living biomass) appears with a pink coloration and, depending on the canopy coverage, with a bright red color. This information is confirmed by the obtained levels (Fig. 2).

Also, as shown in Fig. 2, the near-infrared spectral range $(0.7-0.8 \mu \mathrm{m})$ is represented by band 1 . Note that the graph is regular, clearly showing different units including water and salt marsh. The gray levels (digital numbers - DN) of the lake water (Patos Lagoon) were about $100 \mathrm{DN}$; those of the salt marshes and wetlands areas were $150 \mathrm{DN}$, and those on areas with grass (pasture) and exposed soil (sand dunes) were about $250 \mathrm{DN}$.

Based on the identification of the farm areas, it was noted that most of them was constructed on obliterated dune environments (i.e., dunes that become extinct by the action of the wind) now changed into coastal plains. Such environments are considered ideal for the construction of cultures (Peixoto et al. 2005), and are characterized by low vegetation with low level of ground coverage, being used extensively for cattle pastures and cultivation of onion (Tagliani 2003).

At the location close to farm 5, the destruction of part of the salt marsh area was documented during this 


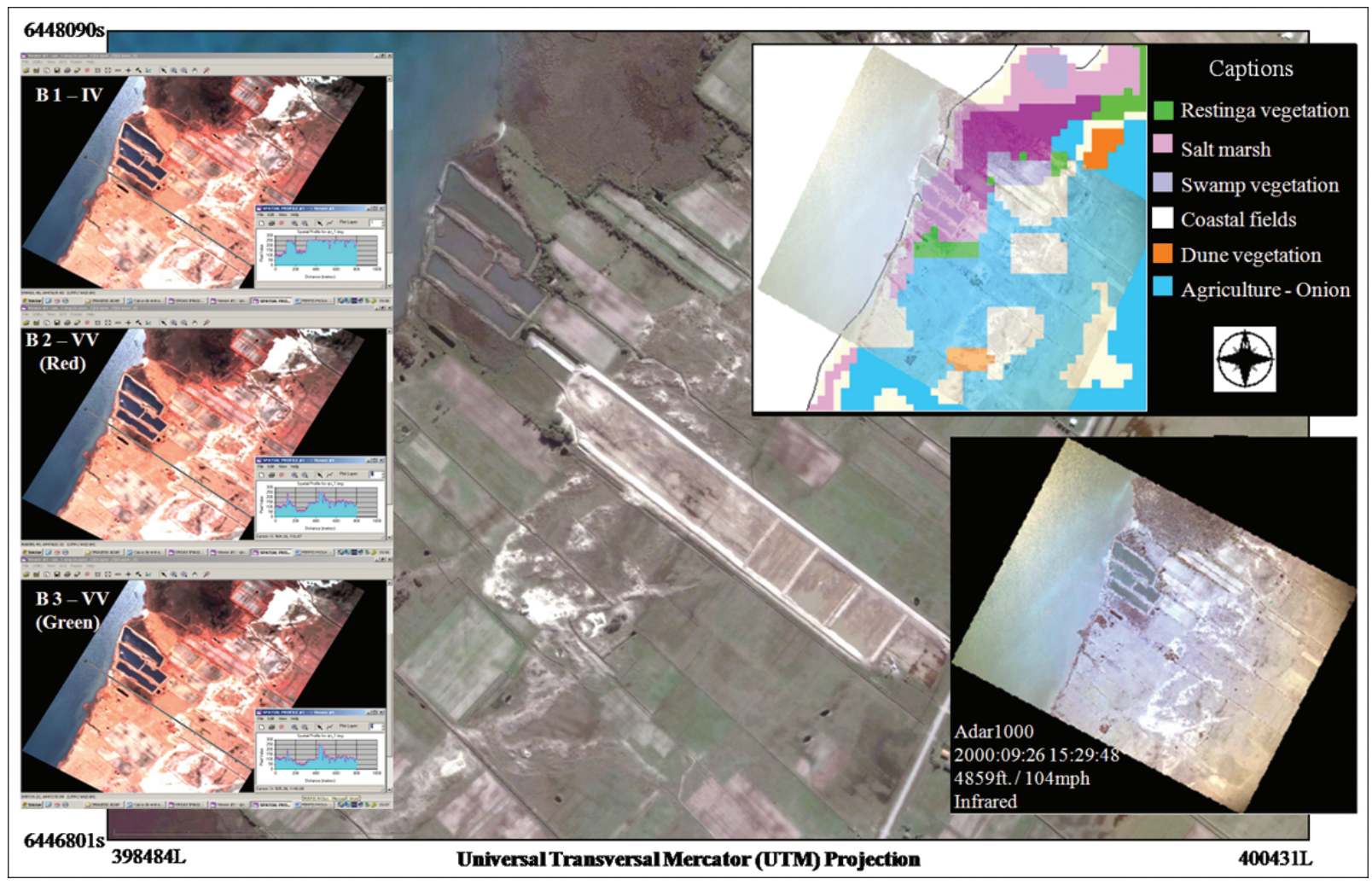

Fig. 2 - Spectral response (ADAR) and salt marsh modification (Google Earth) on shrimp farm area number 5 (São José do Norte).

study. These habitats are legally protected and perform important ecological and economic functions, such as structural protection against the erosion of the coast, hydrological regulation, and shelter for biota (Seeliger and Costa 1997, Tagliani 2003). The area was modified in the 90 's by a small enterprise that did not have legal or technical endorsement, which resulted in the interdiction of the enterprise after three years of functioning. Afterwards, part of the area was purchased by another shrimp producer, who structured his culture according to the environmental legislation.

Regarding farms 1, 2 and 3, it was observed that part of the activities were performed in areas with sand accumulation. These areas consist of littoral fields or dunes changed by time or through cattle raising and agriculture, long before the construction of the farms (Fig. 3).

Seeliger and Costa (1997) reported that the marginal areas of the Patos Lagoon (salt marshes, wetlands and dunes) have been colonized by an intense pasture of bovines and equines since the European occupation of the state of Rio Grande do Sul. The small tide ampli- tude, soft slope and low occurrence of tide canals favor pasturing and environmental changes, with visible differences between areas used for pastures and areas with other uses. Seeliger and Costa (1997) reported an 11\% decrease of the floodable area of the lower portion of the estuary over the last two centuries.

The current proximity of farms 2 and 3 to wetland and salt marsh areas can be explained by animals not getting there, the soil enrichment with nutrients ( $\mathrm{P}$ and $\mathrm{N}$ ) coming from the culture (feed and excrements) and, finally, by the increase of soil humidity due to the construction of canals and ponds. So the area remained "untouched", with a restoration of habitat's physiography and plant diversity.

For the soil classification, Sombroek (1969) used a system developed by the USA Department of Agriculture, because this system is universally known and adapts well to the region, and also because of this temperature and soil. Being so, its soil and temperature is very similar to the ones in many regions in the United States of America. This system was originally created 


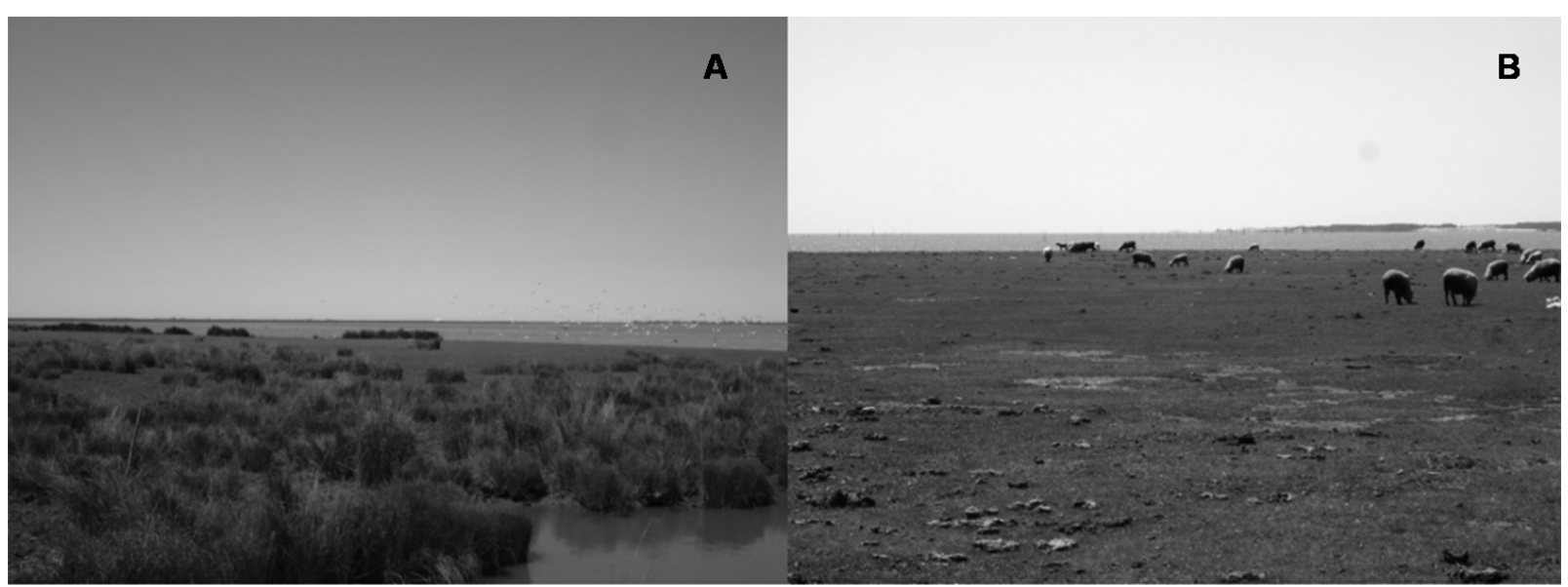

Fig. 3 - Study area landscape. (A: Salt marsh area in São José do Norte; B: Coastal fields also in São José do Norte).

for detailed mapping of cultivated areas, and specially to prevent large scale erosion.

The extreme importance of the danger of erosion, including the slope of the land, was sometimes neglected, being only taken into consideration the possibility of improving the pastures. Sombroek (1969) proposed an adjustment to class $\mathrm{V}$, which, in the USA Department of Agriculture - Soil Conservation Service System (1975), only refers to flat or nearly flat land, and excludes other limitations, such as the danger of erosion. For this author, the modified system is essential in establishing a plan for crops. The classification is a basic criterion for crop lands, pastures or forestry productivity.

In regards to the areas where the aquaculture enterprises are located, it is noted that all of them are above class $\mathrm{V}$, confirming that the areas were chosen in a sufficiently satisfactory manner.

Tagliani (2003), considering possible restrictions in the land use capacity in São José do Norte and Rio Grande, evaluated the limitations inherent to risk conditions, such as draining (d), erosion (e), climate (c), water excess (u) and soil limitations (s). Through this evaluation, soils in all farms were mainly classified as of low drainage capacity and with severe soil limitations, restricting their use for agriculture (Fig. 4).

In the same way, Cunha et al. (1996) reported that, in a general manner, soil of farm 7 is poor, and land use is limited to pastures. Therefore, the low fertility of local soil can favor the use of these areas that are used or not for agriculture and pasture, as well as for culture of aquatic organisms.

Considering the agreement of all enterprises with the current environmental legislation, it was observed in farm 6 , that the commitment of preserving a $15 \mathrm{~m}$ distance buffer zone from public domain roads was not fulfilled. This fact resulted in sanctions by the local environmental agency. The irregularity was detected only in situ due to the fact that the available images (ADAR1000, Landsat and Google Earth) are dated prior to the enterprise setup.

Once again, this fact shows that the experience of the analyst, together with the technological advances (softwares and hardwares), does not prevent the analysis from being affected by errors or inadequate interpretations. Therefore, it is extremely important to perform an in loco verification of the areas.

Little influence of slope and topography was observed, because not only slope (0-5\%), but also topography $(1-4 \mathrm{~m})$, present very few variation, not being an issue when the activity in the region was considered.

Regarding the location of the activity, farms 4 and 5 are the most privileged ones. These farms are closer to the lagoon bar, where south quadrant winds flood the lagoon with seawater and that, together with summer droughts, creates large areas with long periods of brackish water in the estuary (Seeliger and Costa 1997, Peixoto et al. 2005). Farms 6 and 7 are located to the north of the estuary and, therefore, under direct influence of freshwater discharge of the São Gonçalo canal, 


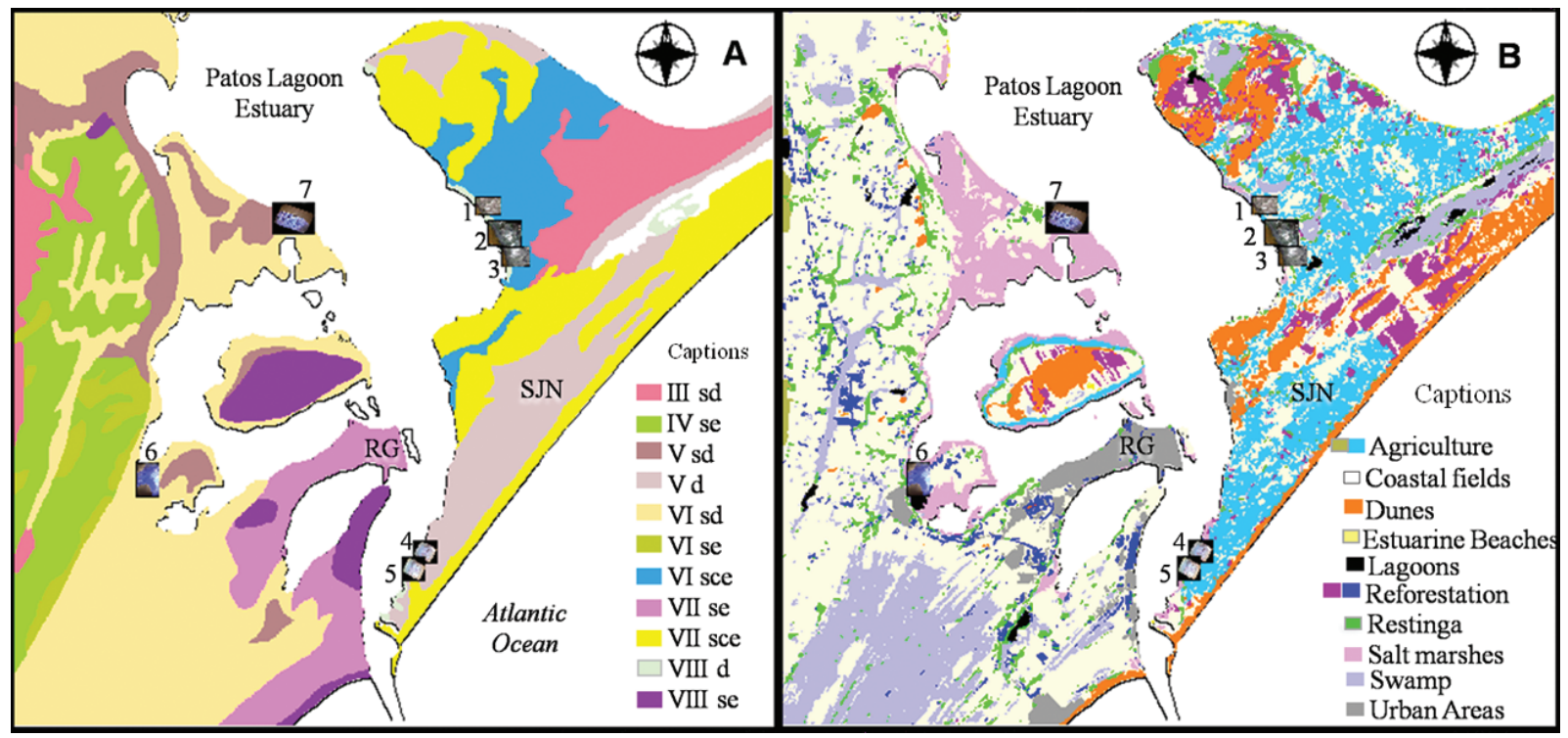

Fig. 4 - (A): Soil classification and its evaluated limitations inherent to risk conditions, such as draining (d), erosion (e), climate (c), water excess (u) and soil limitations (s). (B): Reforestation = Pinus and Eucalyptus; Agriculture = Onion and rice.

being subject to low brackish water availability for the ponds. Seeliger and Costa (1997) also confirm the above statement, reporting that saline water penetration in the marginal estuary area is more dependent on meteorological events, such as wind and precipitation, than on the effect of tide or current variations.

Concerning the climatic conditions, a great variation of temperature and precipitation (with an average of $1250 \mathrm{~mm}$ ) is observed, due mainly to polar fronts. On average, these frontal systems reach the region six or seven times every month, with higher occurrence in winter than in summer (Reed et al. 2009). For this reason, shrimp culture is concentrated during the summer (DecMar), with only one productive cycle.

Finally, in situ photos taken with a CAPLIO 500SE digital camera, allowed the obtention of georeferenced images. This resulted in the direct import of such images into the GIS and offered an immediate recognition of environmental conditions for each studied location.

\section{CONCLUSIONS}

From the results, it was evident that the applied methodology is adequate for the characterization of aquaculture enterprises, construction of an effective GIS database for the activity in the region, as well as the verification of the conformity of environmental legislation by the enterprises.
Difficulties in image interpretation occurred due to different scales of analysis (ADAR 1000, Google Earth, existing database and Landsat), but did not restrain the study, with the in situ investigation being essential for the interpretation of results.

The organization of many information acquisition methods, management tools, searches, and information analysis in one database generated important understanding of the study area and the inherent characteristics of the local activity. This fact will aid, in future studies, the classification of areas with more suitable conditions for new farms setup, generating less socio-environmental impact, productivity increase and preservation of areas that are sensible to environmental changes.

Thus, this study provides a framework and an important set of tools for human activities, helping to understand the dynamics between local natural environment and a potential impact on it. However, if performed in a correct and sustainable way, these activities are capable of generating social and economical wealth for the local population.

\section{ACKNOWLEDGMENTS}

This study was financed by Brazilian Federal Government - Ministério da Ciência e Tecnologia - MCT/CTHIDRO - Fundo Setorial de Recursos Hídricos/Minis- 
tério do Meio Ambiente - MMA/Conselho Nacional de Desenvolvimento Científico e Tecnológico - CNPq.

\section{RESUMO}

No estado do Rio Grande do Sul existem quatro fazendas produtoras de camarões (Litopenaeus vannamei) marinhos nos municípios de São José do Norte e Rio Grande, e outras quatro fazendas já possuem licença prévia. Assim, o presente estudo propôs identificar e caracterizar as áreas destinadas a cultivos de camarões marinhos localizadas na porção sul do estuário da lagoa dos Patos $\left(32^{\circ} 00^{\prime} \mathrm{S} 52^{\circ} 00^{\prime} \mathrm{W}\right)$, empregando análises de sensoriamento remoto orbital (ETM+/Landsat, Google Earth), aéreo (35mm/sistema ADAR 1000), terrestre (RICOH 500SE) e de saídas de campo, integrando os dados num Sistema de Informação Geográfica (IDRISI Andes). Resultados apontaram que os empreendimentos foram construídos sobre campos litorâneos ou em regiões de dunas obliteradas, regiões estas propícias para o cultivo. A proximidade dos possíveis mercados consumidores e mão de obra local, estradas de acesso relativamente boas e suporte técnico local também favorecem os projetos. No entanto, deve haver cautela em termos de mudanças nos projetos originais, o que poderia causar impactos ambientais e descumprimento das normas ambientais, tais como a ocupação de áreas de marismas. A partir das informações obtidas, podem ser criados instrumentos que auxiliarão na tomada de decisões legais para gerenciar a atividade em futuros empreendimentos.

Palavras-chave: gestão costeira, SIG, Lagoa dos Patos, fazendas de camarão.

\section{REFERENCES}

Chen S, Chen L, LiU Q, Li X and Tan Q. 2005. Remote sensing and GIS-based integrated analysis of coastal changes and their environmental impacts in Lingding Bay, Pearl River Estuary, South China. Ocean Coast Manage 48: 65-83.

Civco DL, Kennard WC AND Lefor MW. 1986. Changes in Connecticut salt-marsh vegetation as revealed by historical aerial photographics and computer-assisted cartographics. J Environ Manage 10: 229-239.

Cunha NG, Silveira RJ dA C ANd SEvero CRS. 1996. Estudo dos solos do município de Rio Grande. Pelotas, Brasil: Universitária/UFPel, EMBRAPA/CPACT, 74 p.

FAO - FoOd AND AGRiculture Organization OF the United NATIOns. 1998. FAO Technical Consultation on policies for Sustainable Shrimp Culture. Bangkok, Thailand, 8-11 December 1997. FAO Fisheries Report. No. 572. Rome.

Fontoura JAS And Hartmann C. 2001. Capture Small Format Aerial Digital Images Using the Airborne data Acquisition System (ADAR 1000) from Positive System Company (USA). Pesquisas. Instituto de Geociências da Universidade Federal do Rio Grande do Sul, Instituto de Geociências, UFRG 28: 373-381.

FReitas DM AND TAGLiani PRA. 2007. Spatial Planning of Shrimp Farm Activities in the Patos Lagoon Estuary (Southern Brazil): In a Context of Integrated Coastal Management. J Coastal Res 47: 136-141.

GiAP DH, Yi Y AND YAKUPITIYAGE A. 2005. GIS for land evaluation for shrimp farming in Haiphong of Vietnam. Ocean Coast Manage 48: 51-63.

KAPETSKy JM, Hill JM, Worthy LD AND EVANS DL. 1988. A geographical information system for catfish farming development. Aquaculture 68: 311-320.

Karthika M, Surib J, NeElam S and Biradar RS. 2005. Brackish water aquaculture site selection in Palghar Taluk, Thane district of Maharashtra, India, using the techniques of remote sensing and geographical information system. Aquacult Eng 32: 285-302.

Meyer JW, Frank DJ, Hironaka A, Schofer E AND TUMA NB. 1997. The Structuring of a World Environmental Regime, 1870-1990, International Organization 51: 623-651.

Nath SS, Bolte JP, Ross LG AND Aguilar-ManJaRREZ J. 2000. Applications of geographical information systems (GIS) for spatial decision support in aquaculture. Aquacult Eng 23: 233-278.

Peixoto S, Wasielesky W, CaValli RO, Santos MHS AND PoERSCH LH. 2005. Diretrizes para o desenvolvimento responsável da carcinicultura na região do estuário da Lagoa dos Patos, Rio Grande do Sul, Brasil. Gerenciamento Costeiro Integrado 04: 1-4.

Pérez OM, Telfer TC, Beveridge MCM AND Ross LG. 2002. Geographical Information Systems (GIS) as a Simple Tool to Aid Modelling of Particulate Waste Distribution at Marine Fish Cage Sites. Estuar Coast Shelf Sci 54: 761-768.

Poli CR, Borghetti JR And GRUmann A. 2000. Situação Atual da Aqüicultura na Região Sul. In: POLI CR, BorghetTi JR AND GRUMANN A (Eds), Aquicultura no Brasil: Bases para um desenvolvimento sustentável. Brasília: CNPq/MCT, p. 323-351. 
PRIMAVERA JH. 2006. Overcoming the impacts of aquaculture on the coastal zone. Ocean Coast Manage 49: 531-545.

ReEd AH, FaAs RW, Alisson MA, Calliari LJ, HolLAND KT, OREally S and Vaughan WC. 2009. Characterization of a Mud Deposit Offshore of the Patos Lagoon. Cont Shelf Res 29: 597-608.

Seeliger U AND Costa CSB. 1997. Natural and human impact. In: SeEliger U, Odebrecht C ANd CASTELLO JP (Eds), Subtropical Convergence Environments: the coast and sea in the Southwestern Atlantic. ed. Berlim, Germany: Springer-Verlag, p. 197-203.

Soil Conservation Service System. 1975. Soil taxonomy: a basic system of soil classification for making and interpreting soil surveys. Washington, 503 p. (Agriculture Handbook, 436).
Sombroek WG. 1969. Soil studies in the Merin Lagoon basin. Projeto da Lagoa Mirim. Pelotas: CLM/PNUD/ FAO, v.1.

TAGLiAni CRA. 2003. Mapeamento da vegetação e uso do solo nos entornos do estuário da Laguna dos Patos, RS, utilizando técnicas de processamento digital de imagem do SIG SPRING. Fatorgis In Box, 7 p.

Ustin ST, Adms JB, Elvidge CD, Rejmanek M, Rock BN, Thomas RW ANd WoOdWard RA. 1986. Tematic mapper studies of semiarid shrub communities. Bioscience 36: 446-452. 